\title{
Craniofacial Anthropometry in a Young Nigerian Population: the Canthal Distances
}

\author{
Antropometría Craneofacial en una Población Joven de Nigeria: Distancia Cantal \\ *Blessing N.R Jaja; **Hakeem B Fawehinmi \& ${ }^{* *}$ Joy T. Jack
}

JAJA, B. N. R.; FAWEHINMI, H. B. \& JACK, J. T. Craniofacial anthropometry in a young Nigerian population: the canthal distances. Int. J. Morphol., 29(3):914-917, 2011.

SUMMARY: The measurement of craniofacial parameters have clinical, forensic and anthropologic significance. Local data on inner canthal and outer canthal distances and the canthal index may reveal the pattern of differential growth in craniofacial features resulting from factors such as sex, diet and genetic distinctions. In the present study, we provide normative data on canthal distances in a Nigerian population which has not been studied previously, utilizing a study design which optimises the effect of age and minimise bias and confounding than previous studies in Nigerian groups. The mean inner canthal distance was $1.85 \pm 0.30 \mathrm{~cm}$ and $2.07 \pm 0.29 \mathrm{~cm}$ (males vs. females, $\mathrm{p}=$ 0.000 ); mean outer canthal distance, $10.39 \pm 0.56 \mathrm{~cm}$ and $10.40 \pm 0.98 \mathrm{~cm}$ (males vs. female, $\mathrm{p}=0.899$ ). The results were found to be considerably lower than what has been reported among Nigerian groups.

KEY WORDS: Biological anthropology; Craniofacial anthropometry; Canthal distance; Nigeria; Kalabari.

\section{INTRODUCTION}

Craniofacial anthropometry has assumed much significance in recent times as a result of the relevance which measurement of parameters on the face has to the evaluation of certain syndromic conditions (Farkas et al., 2003). In addition, reconstruction of the canthus following deformities of the orbit, congenital or acquired, presume measurement of the canthal distances to achieve anatomic restitution (Laestadius et al., 1979).

Given that these parameters vary with age, sex and ethnic background, several authors have undertaken to document normative values which may serve as references in the index population. Canthal distances have therefore been documented in Taiwanese (Wu et al., 2000), Chinese (Quant \& Woo, 1992), Mexican and Japanese children (Laestadius et al.), Turkish (Evereklioglu et al., 2002) and Indian subjects (Zuhal, 1994). Comparative data has also been provided among Japanese and Australian aborigine populations (Kasai et al, 1993). In another related study, Kaimbo \& Kayembe (1994) reported on orbital measurements in Zairean children, the inner and outer canthal distances inclusive.

More recently, a few studies examining the canthal distances among Nigerian population groups have appeared in published literature. Saheeb et al. (2004) studied Nigerian subjects aged $3-18$ years with their data not presented along ethnic background. Oladipo et al. $(2008,2009)$ reported on the canthal index of Ijaw and Igbo population groups and the canthal distances of subjects of Urhobo and Itsekiri ethnicity aged $18-45$ yrs. Oyinbo et al. (2008) also studied a subset of the Ijaw population with a similar age range to those of Oladipo and co-workers.

The present study investigated the canthal distances against a narrower age cohort, with subjects having a more homogenous background than those of previous studies among adult Nigerian groups. The study proposes to provide normative data that could be used for clinical assessment, craniofacial surgery and anthropologic evaluation in the index population.

\section{MATERIAL AND METHOD}

Participating subjects for this study were randomly selected from the Kalabari National College in Buguma

\footnotetext{
* Department of Human Anatomy, College of Health Sciences, Niger Delta University, Wilberforce Island, Bayelsa State, Nigeria. **Department of Human Anatomy, College of Health Sciences, University of Port Harcourt, Choba, Rivers State, Nigeria.
} 
town, Rivers State of Southern Nigeria. The subjects who were within the age range of $16-18$ years, all had parents and grandparents of Kalabari nativity who lived in the same area of Southern Nigeria as the subjects. The participants did not have craniofacial defects and all voluntarily consented to the study, which was conducted according to the tenets of the declaration of Helsinki (WMA, 2008). There were 408 subjects in all comprising 204 male and 204 female participants. The technique that was used for measuring the studied parameters were similar to those of Evereklioglu et $a l$. Each participant was comfortably seated in a chair with his/her face properly illuminated and the head held straight to face the examiner's. The inner canthal distance (ICD) was measured as the distance between the medial angle of the left eye and the medial angle of the right eye. The outer canthal distance (OCD) was measured as the distance between the lateral angle of the left eye and the lateral angle of the right eye. All measurements was performed by a single investigator and by aid of a vernier calliper with measurement accuracy of $0.1 \mathrm{~mm}$. Each measurement was undertaken twice and the average computed. We computed the canthal index (CI) as [ICD x 100]/OCD and the palpabral fissure length (PFL) as $[\mathrm{OCD}$ - ICD]/2. The difference between mean values was tested for statistical significance using the one way ANOVA. Probability values greater than 0.05 were considered as insignificant.

\section{RESULTS AND DISCUSSION}

The obtained data in sampled subjects are as summarized in Table I. Significant sex differences were found in ICD and in CI but not in OCD, with mean values in females greater than mean values in male subjects. The PFL was significantly wider in the males in comparison to the females. On comparing the obtained results to those previously published on Nigerian populations (Tables II and III), it was seen that mean values of ICD, OCD and CI in sampled subjects were considerably lower than values reported for the Ijaw, Urhobo and Itsekiri population groups, in both sexes.

Comparative analysis of canthal parameters across different populations has yet to establish a consistent pattern of sex differences, although generally, normative values tend to be greater in males as compared to those of female subjects. Relatively greater mean values for ICD and OCD has been reported in males as compared to females in studies carried out among subjects of Turkish (Evereklioglu et al.) and Latvian (Nagle et al., 2005) extractions as it is also among the Ijaw, Urhobo and Itsekiri groups of Nigeria (Tables I and II). However, among the subjects of this present study, the converse was observed to be the case. In a study by Abdulla (2002) on a population of Saudi Arabian subjects, a greater average value for females in ICD as compared to their male counterparts was also reported. In the parameter of canthal index, the pattern of sex difference among our subjects is similar to what is seen among the itsekiri group of Nigeria, African American (Juberg et al., 1975), and Indian (Singh \& Banerjee, 1983) subjects but at variance with findings among studied(mean values in $\mathrm{cm}$ ).

\begin{tabular}{lcccccc}
\hline Study & Year & Population & n & ICD & OCD & CI \\
\hline Oyinbo et al. & 2008 & Ijaw & 185 & $3.91 \pm 0.32$ & $10.40 \pm 0.98$ & - \\
Oladipo et al. & 2009 & Urhobo & 250 & $3.00 \pm 0.39$ & $12.10 \pm 0.21$ & 29.38 \\
Oladipo et al. & 2009 & Itsekiri & 250 & $3.30 \pm 0.12$ & $11.40 \pm 0.55$ & 27.70 \\
Present study & 2009 & Kalabari & 204 & $2.07 \pm 0.29$ & $10.40 \pm 0.98$ & 20.08 \\
\hline
\end{tabular}


the Ijaw and Igbo groups of Nigeria, as it is also with data on Turkish and Latvian subjects, in whom greater values of canthal index are seen in males as compared to females. Sex differences in canthal measurements are attributable to genetic and environmental factors, as are differences seen across age and ethnic background (Oyinbo et al.).

The present study has revealed that among adult Nigerian populations previously studied, the sampled population has the lowest values of ICD, OCD and canthal index. Oladipo et al. (2009) reported mean canthal index among the Ijaw to be 37.04 in males, 33.11 in females and among the Igbo, they reported values of 35.15 in males and 32.59 in females. Although the differences seen in canthal parameters in studied Nigerian populations appear to suggest ethnic variations, these are more appropriately a reflection of the age differences in the subject sets used in the different studies. The subjects of our present study are younger and of a closer age cohort than those of similar studies among the Nigerian groups under review. Younger populations tend to have lower values of ICD, OCD and CI in comparison to older populations and generally, canthal measurements become constant in the third decade of life (Pryor, 1969; Fledalius \& Stubgaard, 1986).

Interestingly, prior to recent studies that examined canthal indices in adult Nigerian groups, three relatively older studies have proposed normal values for facial measurements in newborns of Nigerian mothers. The findings of these studies could however not be generalized as the infants were of mothers who are predominantly of the Yoruba tribe of western Nigeria (Ogunye et al., 1982; Ejiwunmi et al., 1984; Omotade, 1990). These studies though were consistent with the observation that the negroid neonate is hyperteloric with respect to the outer canthal distance, but not to the inner canthal distance. The study of Omotade, in particular, provided data on palbabral fissure length, being the other to do so in a Nigerian cohort, besides the present study. It reported an average PFL of $2.3 \mathrm{~cm}$ for both male and female Yoruba newborns, which was significantly higher than the average values in Caucasian newborns, suggesting that the wider palpabral fissure length of negroid newborns should be taken into consideration while examining for congenital glaucoma in newborns of African descent. In the present study, the PFL was twice the value reported for the newborn infants.

Indeed, dysmorphic craniofacial features may be apparent in individuals with syndromic conditions such as Apert's, Crouzon's, Robinson's syndromes, trisomy 13, Williams, and the Meckel-Gruber syndromes. In unaffected family relatives who may harbour subtle facie, benefit from genetic counselling may require, as a screening procedure, measurements of the craniofacial parameters considered in this report. These parameters may also be useful for preliminary identification purposes in settings were robust forensic procedures are in limited supply. The present study has provided normative data in a Nigerian group hitherto not investigated. Its advantage over previous studies on adult Nigerian groups is that it optimizes the effect of age on canthal variables by sampling a narrower age cohort close to the point of maximum growth of the canthi. Also, the homogenous background of the sampled population, who are all from the same community, minimises bias and confounding. The data therefore has utility for craniofacial assessment, surgery and forensic investigations in the index population.

\section{ACKNOWLEDGEMENTS}

We would like to express our gratitude to the subjects who participated in this study

JAJA, B. N. R.; FAWEHINMI, H. B. \& JACK, J. T. Antropometría craneofacial en una población joven de Nigeria: distancia cantal. Int. J. Morphol., 29(3):907-913, 2011.

RESUMEN: La medición de parámetros craneofaciales tiene importancia clínica, forense y antropológica. Los datos locales sobre la distancia cantal interna y cantal externa y el índice cantal puede revelar el patrón de crecimiento diferencial en las características craneofaciales como resultado de factores como el sexo, la dieta y las diferencias genéticas. En el presente estudio, se proporcionan datos normativos sobre la distancia cantal en una población de Nigeria que no ha sido estudiada previamente, utilizando un diseño de estudio que optimiza el efecto de la edad, como también minimiza el sesgo y la confusión de estudios anteriores en los grupos de Nigeria. La media de distancia cantal interna fue de $1,85 \pm 0,30 \mathrm{~cm}$ y $2,07 \pm 0,29 \mathrm{~cm}$ (hombres v/s mujeres, $\mathrm{p}=0,000$ ), mientras que la media de distancia cantal externa fue $10,39 \pm 0,56 \mathrm{~cm}$ y $10,40 \pm 0,98 \mathrm{~cm}$ (hombres $\mathrm{v} / \mathrm{s}$ mujeres, $\mathrm{p}=0,899$ ). Los resultados de este estudio son considerablemente más bajos que lo que se han reportado previamente para los grupos nigerianos.

PALABRAS CLAVE: Antropología biológica; Antropometría craneofacial; Distancia cantal; Nigeria; Kalabari. 


\section{REFERENCES}

Abdullah, M. A. Inner Canthal distance and geometric progression as a predictor of maxillary central incisor width. J. Prost. Dent., 88(1):16-20, 2002.

Ejiwunmi, A. B.; Okanlawon, O. A. \& Ojo, O. O. Interpupillary and internipple distances and ear lengths in Nigerian newborns. Ann. Trop. Paediatr., 4(2):103-6, 1984.

Evereklioglu, C.; Doganay, S.; Hamdi, E. R.; Gunduz, A.; Tercan, M.; Balat, A. \& Cumurcu, T. Craniofacial anthropometry in a Turkish population. Cleft Palate Craniofac. J., 39(2):208-18, 2002.

Farkas, L. G.; Hreozko, T. M.; Katic, M. J. \& Fornest, C. R. Proportion indices in the craniofacial regions of 284 healthy North American white children of 1 and 5 years of age. J. Craniofac. Surg., 14(1):13-28, 2003.

Fledalius, H. C. \& Stubgaard, M. Changes in eye position during growth and adult life as based on exophthalmometry interpupillary distance and orbital distance measurement. Acta Ophtamol., 64(5):481-6, 1986, 1986.

Juberg, R. C., Sholte, F. G. \& Touchstone, W. J. Normal values for intercanthal distances of 5 to 11 year old American blacks. Paediatrics, 55(3):431-6, 1975.

Kaimbo, D. K. \& Kayembe, D. Orbital measurements in Zairian children. Inner canthal, outer orbital, interpupillary distances and proptosis. J. Fr. Ophtalmol., 17(8-9):496-500, 1994.

Kasai, K.; Richards, L. C. \& Brown, T. Comparative study of craniofacial morphology in Japanese and Australian aboriginal populations. Hum. Biol., 65(5):821-34, 1993.

Laestadius, N. D.; Aese, J. M. \& Smith, D. N. Normal canthal and outer orbital dimensions. J. Pediatr., 74(3):465-8, 1969.

Nagle, E.; Teibe, U. \& Kapoka, D. Craniofacial anthropometry in a group of healthy Latvian Residents. Acta Medica Lituanica, 12(1):47-53, 2005.

Ogunye, O.; Ikeji, M. O. \& Adeodu, O. Craniofacial dimensions in the African neonate. Niger. J. Paediatr., 9:21-5, 1982.
Oladipo, G. S.; Fawehinmi, H. B. \& Okoh, P. D. Canthal indices of Urhobo and Itsekiri Ethnic groups. Aust. J. Basic \& Appl. Sci., 3(4):3093-6, 2009.

Oladipo, G. S.; Olotu, E. J. \& Gwurineama, I. U. Anthropometric comparison of canthal indices between the Ijaw ad Igbo tribes. Scientia Africana, 7(1):141-4, 2008.

Omotade, O. O. Facial measurements in the newborn (towards syndromic delineation). J. Med. Genet., 27(6):358-62, 1990.

Oyinbo, C. A.; Fawehinmi, H. B.; Dare, N. W. \& Berezi, M. A. Normal inner and outer measurements of the Ijaws of Southern Nigeria. Eur. J. Sci. Res., 22(2):163-7, 2008.

Pryor, H. B. Objective measurement of interpupillary distance. Paediatrics, 44(6):973-7, 1969.

Quant, J. R. \& Woo, G. C. Normal values of eye position in the Chinese population of Hong Kong. Optom. Vis. Sci., 69(2):152-8, 1992.

Saheeb, B. D.; Umweni, A. A.; Obuekwe, O. N. \& Folaranmi, N. Medial and lateral canthal distances in 3-18 year old Nigerian. West Afr. J. Med., 23(2):156-61, 2004.

Singh, J. R. \& Banerjee, S. Normal values of interpupillary, intercanthal and outer canthal distances in an Indian population. Hum. Hered., 33(5):326-8, 1983.

World Medical Association, WMA. Declaration of Helsinki - Ethical Principles for Medical Research Involving Human Subjects. http://www.wma.net/en/ 30publications/10policies/b3/index.html, 2008.

Wu, K. H.; Tsai, F. J.; Li, T. C.; Tsai, C. H.; Peng, C. T. \& Wang, T. R. Normal values of inner canthal distance, interpupillary distance and palpebral fissure length in normal Chinese children in Taiwan. Acta Paediatr. Taiwan, 41(1):22-7, 2000.

Zuhal, S. Craniofacial anthropometry of Kabui Naga. Anthropologist, 8(1):1-3, 1994.

Correspondence to:

Dr. Blessing N.R Jaja

Department of Human Anatomy

College of Health Sciences, Niger Delta University

Wilberforce Island, Bayelsa State

NIGERIA

Received: 09-05-2011

Email: jajabnr2000@yahoo.com
Accepted: 18-06-2011 